\title{
Pesan Dakwah dalam Novel Bait Surau
}

\author{
Muhamad Ripai*, Ucin Muksin, \& Dadan Anugrah \\ Jurusan Komunikasi dan Penyiaran Islam, Fakultas Dakwah dan Komunikasi, \\ UIN Sunan Gunung Djati Bandung \\ *Email:mubamad.ripai@student.uinsgd.ac.id
}

\begin{abstract}
ABSTRAK
Tulisan ini menjelaskan bentuk pesan dakwah yang terdapat dalam novel Bait Surau, baik dari segi imbauan pesan yaitu imbauan rasoinal, imbauan emosional, imbauan takut, imbauan ganjaran dan imbauan motivasional. Dan juga dari segi kategori pesan yaitu kategori substansi dan kategori bentuk. Kategori substansi meliputi akhlak, ibadah dan syariah. Kategori bentuk meliputi informatif, persuaasif dan instruktif. Metode yang digunakan dalam penelitian ini adalah metode analisis isi (content analysis). Hasil penelitian menunjukkan bahwa berdasarkan hasil penelitian dapat disimpulkan bahwa novel ini terdapat banyak muatan pesan-pesan dakwah Islam. Pesan-pesan tersebut terwujud dalam imbauan dan kategori pesan yang mengindikasikan pesan dakwah. Peneliti menghimpun ungkapanungkapan tersebut melalui kategorisasi pesan dakwah. Terdapat dua pesan dakwah berdasarkan jenisnya, yaitu: pesan dakwah dari imbauan dan pesan dakwah dari kategori pesan. Pesan dakwah dari segi imbauan terdapat imbauan motivasional yang paling banyak disebutkan. Adapun dari segi kategori substansi yaitu akhlak dan kategori bentuk informatif, yang paling banyak disebutkan. Selain itu Bait Surau merupakan sebuah novel yang bercerita tentang seorang yang mempunyai masa kelam, dia ingin berubah kearah yang lebih baik dan berjuang membangun surau yang kondisinya memprihatinkan.
\end{abstract}

Kata Kunci: Dakwah, Pesan Dakwah, Novel.

\section{ABSTRACT}

This paper describes the form of dakwah message contained in novel Bait Surau, both in terms of appeal message that is rasoinal appeal, emotional appeal, appeal of fear, appeal ganharan and motivational appeal. And also in terms of the category of the message category of substance and form categories. Substance categories include morals, 
Muhamad Ripai, Ucin Muksin, \& Dadan Anugrah

worship and sharia. Categories of form include informative, persuaasif and instructive. The method used in this study is the method of content analysis (content analysis). The results showed that based on the results of the study can be concluded that this novel there are many cargo messages of Islamic da'wah. The messages are manifested in the Immunizations and Categories of messages that indicate the message of da'wah. Researchers collect these phrases through the categorization of da'wah messages. there are two messages of $d a^{\prime} w a h$ by type, namely: the message of da'wah of the appeal and message propaganda of the message category. The message of da'wah in terms of appeal is the most widely mentioned motivational appeal. As for the terms of Substance Category namely Morals and Informative Form Categories, the most widely mentioned. Besides the Temple of Surau is a novel that tells of a man who has a dark time, he wants to change towards a better and struggling to build a surau whose condition is apprehensive. Keywords: Dakwah, Dakwah Message, Novel.

\section{PENDAHULUAN}

Perkembangan teknologi komunikasi dewasa ini telah jauh dan semakin beragam, namun teknologi penulisan merupakan tahap yang tidak pernah lekang, malahan terus berkembang. Apalagi saat ini ketika "kran" kebebasan membuka penerbitan dibuka lebar setelah reformasi. Kini semakin banyak media surat kabar dan majalah. Masyarakat pun dengan leluasa bisa memilih media yang disukainya.

Situasi demikian adalah peluang sekaligus tantangan bagi para da'i, akankah hanya berdakwah melalui ceramah atau pengajian? Bukankah yang biasa datang ke tempat pengajian terbatas orangnya dan rata-rata orang yang sadar dan shaleh? Bagaimana halnya dengan sejumlah kalangan lain yang tidak sempat datang kepengajian karena sibuk, mereka yang biasa mencari informasi hanya dengan bacaan-bacaan. Jika para da'i hanya mengandalkan dakwah bi al-lisan saja, dan hanya sebagai konsumen untuk informasi yang disampaikan oleh media lain, maka salah satu lahan potensial tidak digarap.

Oleh karena itu, tidak keliru jika kini kegiatan dakwah bisa dikembangkan melalui media tulisan. Melalui tulisan yang dikemas secara populer. Pesan dakwah dapat tersebar dan diterima banyak kalangan, dalam waktu pengaksesannya tegantung kepada keluangan mad'u (objek dakwah). Disamping itu, melalui tulisan yang dimuat di media massa, tulisan dakwah dapat memberikan "warna dakwah" terhadap pesan yang berkembang dewasa ini. Alangkah disayangkan jika suatu media terpaksa menampilkan tulisan-tulisan yang kurang bermutu, apalagi yang "picisan" dan "kekuning- 
kuningan" hanya karena jarang tulisan dakwah (Kusnawan, 2004: 23).

Keunggulan novel sebagai sarana dakwah yaitu untuk menjadikan jangkauan dakwah lebih luas dengan menggunakan media cetak, dalam hal ini novel ternyata jangkauannya lebih luas dibandingkan dengan media yang lain, sebab tidak mengharuskan dengan cara langsung (face to face) antar da'i dan mad'u dan dapat menjangkau ke semua tempat.

Selain itu novel juga repeatable, yakni dapat di baca berkali-kali dengan menyimpannya, sehingga suatu saat diperlukan dapat dilihat dan dibaca kembali. tidak membutuhkan waktu yang khusus, dakwah yang dikemas dalam bentuk novel bisa dinikmati kapan saja dan dimana saja berada serta dapat diulang-ulang sesuai dengan kesempatan yang ada sehingga dapat meninggalkan kesan yang lebih kuat.

Salah satu novel yang mempunyai ciri khas tersendiri dalam menyampaikan pesan-pesan kebaikan, yaitu novel berjudul Bait Surau karya Rakha Wahyu \& Yus R. Ismail. Novel ini dapat memberikan dorongan motivasi dan mengajak para pembaca menuju jalan yang lebih baik. Novel Bait Surau ini dapat menginspirasi banyak orang sehingga ceritanya masuk disemua kalangan, pesannya mudah terserap serta dapat diterima oleh masyarakat luas. Hal yang Menarik dari novel Bait Surau, bagaimana penulis menyikapi tentang masa lalu. Masa lalu adalah milik masa kini. Masa lalu seburuk apapun itu adalah milik seseorang yang harus diterimanya, dengan lapang dada. Rommy, tokoh utama dalam Novel Bait Surau. Menggambarkan seseorang yang pernah gagal menerima cinta dan menghargai cinta dengan semestinya.

Cinta yang berlebihan terhadap dunia, wanita dan materi hanyalah menumpuk kegelisahan. Dan manusia tidak mungkin sanggup terus menerus menanggung gersang dalam hatinya. Manusia butuh cinta yang menyejukan pikiran dan berperilaku serba ikhlas.

Novel Bait Surau memberikan banyak pelajaran berharga bagi para pembaca, karena di dalamnya terdapat masukan-masukan positif. Ceritannya sangat universal soal cinta, universal soal religi dan bisa membawa suasana hati menjadi tenang.

Novel Bait Surau bisa menjadi media dakwah yang bisa diterima oleh khalayak banyak. Sebagai bahan bacaan yang bisa dijadikan sebagai hiburan ditengah-tengah kesibukan sehari-hari, sumber tambahan informasi dan lain-lain. Selain itu, novel Bait Surau ini bisa menjadi penyemangat untuk menumbuhkan motivasi dalam berbuat kebaikan dan juga dapat menjadi bahan renungan yang berguna agar kita bisa terhindar dari perilaku yang 
Muhamad Ripai, Ucin Muksin, \& Dadan Anugrah

bisa menimbulkan penyesalan dan kerugian.

Selain itu alur cerita novel Bait Surau banyak memuat pesan-pesan dakwah, pesannya mudah diserap dan juga dipahami, novel Bait Surau baik untuk dibaca oleh masyarakat umum, maka dari itu penulis bermaksud untuk meneliti novel tersebut. Penelitian ini mengenai pesan-pesan apa saja yang terdapat pada novel Bait sebagai bahan kajian dalam penyusunan skripsi dengan mengambil judul pesan dakwah dalam novel Bait Surau (Studi Analisis Isi Pesan Dakwah dalam Novel Bait Surau).

Ali Mahfudz memberikan pemahaman bahwa dalam berdakwah memiliki urutan dan unsur atau komponen yang terdiri dari da'i, pesan, metode, mad'u dan tujuan yang akan dicapai. Analisis isi pesan dalam novel surga untuk anakku bisa dilakukan dengan dua cara menurut Rahmat (2005: 294), yaitu dengan cara melalui imbauan pesan, dan kategori pesan dalam novel.

Oleh karena itu, suatu pesan bisa disebut pesan dakwah apabila mengandung seluruh ajaran Islam yang terdapat di dalam sumber ajarannya yaitu Al-Qur'an dan As-Sunnah. Dalam hal ini novel Bait Surau memuat pesan dakwah melalui kata-kata atau pernyataan-pernyataan yang mengindikasikan sebagai pesan dakwah baik berupa imbauan pesan maupun kategori pesan dakwah.

Para peneliti psikologi komunikasi telah meneliti efektivitas imbauan pesan. Apakah komunikasi akan lebih terpengaruhi oleh imbauan emosional atau imbauan rasional? Apakah komunikate akan lebih tergerak oleh imbauan ganjaran daripada imbauan takut? Motif-motif apakah yang dapat kita sentuh dalam pesan kita supaya kita berhasil mengubah sikap dan perilaku komunikan? (Rakhmat, 2011: 294).

Dasar pemikiran dalam mencari pesan dakwah yang terdapat dalam novel Bait Surau adalah imbauan apa saja yang terdapat didalam novel Bait Surau baik berupa imbauan rasional, imbauan emosional, imbauan takut, imbauan ganjaran dan imbauan motivasional menurut (Rakhmat, 2011: 294). Dan juga kategori pesan dakwah apa saja yang terdapat dalam novel Bait Surau baik dari segi kategori substansi yaitu berupa akhlak, ibadah dan syariah dan juga dari segi kategori bentuk pesan yaitu berupa informasi, persuasi dan intruksi.

Dari uraian di atas, maka dapat dirumuskan permasalahan yang akan diteliti, rumusan masalahnya adalah Bagaimana bentuk imbauan pesan dakwah dalam novel Bait Surau, dan Bagaimana bentuk kategori pesan dakwah dalam novel Bait Surau. 


\section{METODE PENELITIAN}

Metode penelitian ini ditunjukan untuk menggali lebih dalam lagi mengenai pesan dakwah yang terdapat dalam novel Bait Surau. Metode yang digunakan yaitu metode analisi isi (content analysis) yakni untuk memperoleh keterangan dari pesan dakwah yang disampaikan dalam novel Bait Surau.

Metode analisis bertujuan untuk mengkaji apa dan bagaimana pesan dakwah dalam novel Bait Surau, menganalisis seluruh isi novel, menemukan berbagai imbauan maupun pesan dakwahnya dan kategori substansi dan kategori bentuk pesan dakwahnya, untuk mengetahui bagaimana fungsi tiap-tiap pesan tersebut, dengan cara mencari, menyusun dan mengklasifikasikan ungkapan-ungkapan dalam keseluruhan teks novel Bait Surau.

Jenis data dalam penelitian ini yaitu segala informasi yang berkaitan dengan imbauan dan kategori pesan dakwah yang terdapat dalam novel Bait Surau, jenis data ini dibagi pada dua bagian primer dan sekunder: Jenis data primer adalah segala informasi yang berkaitan dengan masalah penelitian yang bersumber dari tangan pertama (first hand), baik berupa pandangan, pikiran, karya, sikap, perilaku, dan lain-lain. Jenis data sekunder adalah segala informasi yang berkaitan dengan masalah penelitian yang bersumber dari tangan kedua (second hand), baik berupa pandangan, pikiran, karya, sikap, perilaku dan lain-lain.

Sumber berkaitan dengan penelitian ini yang mengkhususkan pada pengkajian-pengkajian pesan-pesan dakwah pada novel, jenis data yang digunakan pleh peneliti adalah jenis data tertulis, dalam penelitian tersebut, data yang digunakan untuk menganalisis pesan dakwah yang berkaitan dengan berbagai imbauan dan kategori pesan dakwah yang termuat dalam novel Bait Surau. Jenis data ini meliputi, kata, kalimat, paragraf, ungkapan, alur cerita da nisi pesan.

Sumber data primer adalah sumber data yang langsung memberikan data kepada pengumpul data (Sugiyono, 2012: 225), adapun sumber data primer dalam penelitian ini adalah novel Bait Surau karya Rakha Wahyu dan Yus R Ismail penerbit Two Synergy Publisher cetakan pertama tahun 2012.

Sumber data sekunder adalah sumber yang tidak langsung memberikan data kepada pengumpul data (Sugiyono, 2012: 225), adapun sumber data sekunder dalam dari penelitian ini adalah buku-buku lain yang berkaitan dengan novel Bait Surau serta mengambil informasi dari Rakha 
Muhamad Ripai, Ucin Muksin, \& Dadan Anugrah

Wabyu \& Yus R Ismail dan buku-buku pendukung lainnya.

Teknik pengumpulan data yang dilakukan umumnya menggunakan beberapa cara, antara lain: observasi (observation), wawancara (interview), angket (questionary), dan dokumentasi (documentation), namun pada penelitian ini penulis menggunakan teknik studi dokumentasi. Studi Dokumentasi, Proses pengumpulan data yang diperoleh melalui dokumen-dokumen. Ia berupa, buku catatan, arsip, surat-surat, majalah, surat kabar, jurnal, laporan penelitian dan lain-lain. Ragam teknik pengumpulan data yang digunakan peneliti dalam kegiatan penelitiannya harus sebutkan secara tersurat. Hanya ragam jenis teknik pengumpulan data mana yang dipilih (digunakan) disesuaikan dengan jenis, masalah dan tujuan penelitian. Teknik Dokumentasi atau Studi Dokumentasi, digunakan untuk menunjang dan memperkuat hasil penelitian. Oleh karena itu, untuk memperoleh data-data yang berkaitan dengan permasalahan yang diteliti, penulis melakukan studi dokumentasi melalui novel Bait Surau dan buku-buku lainnya yang masih ada hubungannya dengan penelitian.

Sebagaimana dikemukakan oleh Krippendorff (1991: 275) bahwa analisis isi harus menunjukan perhatian kepada dua jenis realitas, realitas data dan realitas yang ingin penulis teliti. Karena itu, data yang berhasil dikumpulkan kemudian diklasifikasikan sesuai dengan tujuan penelitian. Klasifikasi data tersebut dilakukan dengan menghubungkan satu sama lainnya, sehingga memberikan gambaran tertentu mengenai analisis pesan dakwah dalam novel Bait Surau kemudian dijelaskan berdasarkan kerangka pemikiran dan landasan teoritis, yaitu dengan cara mengkategorisasikan pesan dakwah sehingga diperoleh kesimpulan umum tentang masalah tersebut.

Proses analisis data dimulai dengan menelaah seluruh data yang tersedia dalam berbagai sumber, yaitu dari pengamatan yang sudah dituliskan dalam catatan lapangan, dokumen pribadi, dokumen resmi, gambar dan sebagainya, Analisis data ini dilakukan dengan Reduksi data yaitu setelah data terkumpul kemudian mengadakan langkah reduksi data yang dilakukan dengan cara membuat abstraksi. Abstraksi merupakan membuat rangkuman yang inti, tentang proses dan pernyataan-pernyataan yang perlu dijaga sehingga tetap berada didalamnya (Malaong, 2004: 190).

Analisis lsi dilakukan kepada data yang sudah terkumpul kemudian di analisis sesuai dengan tahapan analisis isi antara lain mengklasifikasikan sesuai dengan tujuan penelitían, menganalisis data sesuai dengan tujuan penelitian, dan mengambil kesimpulan tentang plot atau alur cerita yang 
terdapat dalam novel Bait Surau dengan Pesan-Pesan dakwah yang terkandung di dalamnya.

\section{HASIL DAN PEMBAHASAN}

Bait Surau merupakan novel yang di tulis oleh Rakha Wahyu dan Yus Richyana Ismail. Cerita Bait Surau mengisahkan tentang kehidupan Rommy yang digambarkan sebagai pria yang tidak pernah puas dengan kehidupannya. Hidup Rommy lebih banyak di habiskan dengan menyianyiakan segala yang dia miliki. Mulai dari mabuk-mabukan, keluar malam hingga sifatnya yang suka sekali berganti-ganti wanita. Padahal Romy telah memiliki seorang isteri yaitu Nadia. Apalagi Nadia terkenal dengan sifatnya yang terpuji dan akhlaknya yang mulia. Namun sepertinya hal tersebut belum pernah membuat Rommy berhenti dengan segala sifatnya yang buruk. Karena Rommy seakan tidak pernah mensykuri segala sesuatu yang telah ia miliki.

Suatu kali karena tidak tahan dengan sifat suaminya, Nadia memutuskan untuk menegur Rommy dan berharap dia bisa memperbaiki segala sifatnya yang buruk tersebut. Namun alih-alih mendengarkan nasihat dari isterinya, Rommy merasa Nadia terlalu ikut campur dengan hidup yang ia pilih. Mereka berdua pun terlibat dalam pertengkaran yang hebat. Tidak satupun dari mereka yang memutuskan untuk menghentikan pertengkaran tersebut.

Bahkan pertengkaran tersebut terus berlangsung ketika mereka berdua sedang berada di dalam mobil. Pertengkaran yang terjadi membuat Rommy tidak berfokus pada kemudinya. Sehingga mobil yang mereka tumpangi mengalami kecelakaan hebat. Rommy memang selamat dari kecelakaan tersebut, namun sayang, isterinya yaitu Nadia meninggal akibat kecelakaan tersebut, Rommy dirundung rasa bersalah yang besar. Kemudian dia mulai menyadari kesalahannya selama ini dan telah menyianyiakan orang yang berharga dalam hidupnya. Namun penyesalan tersebut tidak bisa membuat Nadia hidup kembali.

Hingga untuk mendamaikan dirinya sendiri, Rommy memilih pergi ke sebuah desa pesisir. Di sanalah dia menemukan berbagai peristiwa yang menyadarkan dirinya atas semua kesalahan yang telah ia lakukan dalam hidupnya. Termasuk sifatnya yang selalu menyia-nyiakan segala hal yang berharga dalam hidupnya.

Kemudian Rommy juga bertemu dengan Siti, seorang gadis tuna wicara yang mengajarkan banyak hal kepada Rommy. Dari berbagai macam 
Muhamad Ripai, Ucin Muksin, \& Dadan Anugrah

hal tersebutlah, Rommy kemudian dapat menjadi pribadi yang baru dan lebih baik.

\section{Imbauan Pesan Dakwah dalam Novel Bait Surau}

Berdasarkan hasil analisis terhadap penjelasan serta ungkapan-ungkapan di dalam novel Bait Surau mengenai Imbauan Pesan Dakwah, maka kesemuanya itu dapat dimasukan ke dalam sebuah tabel sebagai berikut:

Tabel 1. Presentase Imbauan Pesan

\begin{tabular}{cccc}
\hline Imbauan Pesan & Halaman & Keterangan & Jumlah \\
\hline Rasional & $42,121,127,128,132$ & $121(2 \mathrm{X})$ & 6 \\
Emosional & $43,74,75,76,77,78$, & $77(2 \mathrm{X})$ & 12 \\
Takut & $84,85,86,87,104$ & $76(2 \mathrm{X})$ & 7 \\
Ganjaran & $53,76,83,97,121,122$ & - & 2 \\
Motivasional & 126,132 & $99(3 \mathrm{X}), 100(2 \mathrm{X}), 108$ & 15 \\
& $100,103,108,109$ & $(2 \mathrm{X}), 109(2 \mathrm{X})$ & 42 \\
\hline
\end{tabular}

Dari keterangan tabel 1 diketahui bahwa pesan-pesan dakwah yang terdapat pada novel Bait Surau banyak membahas yang termasuk ke dalam Imbauan Motivasional, sedangkan yang paling sedikit bahasannya terdapat pada Imbauan Ganjaran.

Terhitung dari segi imbauan pesan terdapat 42 ungkapan yang mengindikasikan pesan dakwah yaitu imbauan rasional disebutkan sebanyak 6 kali, imbauan emosional 12 kali, imbauan takut 7 kali, imbauan ganjaran 2 kali, imbauan motivasional 15 kali.

Dan hasil penelitian pada novel Bait Surau di atas dapat ditarik kesimpulan bahwa pesan yang lebih banyak di bahas dalam novel ini adalah mengenai imbauan motivasional.

Imbauan rasional berfungsi untuk mempengaruhi dan menyakinkan orang lain dengan pendekatan logis atau penyajian bukti-bukti komunikasi dengan menyajikan beragam bukti-bukti yang ada. Imbauan emosional berfungsi untuk menyentuh emosi komunikan (Aripudin, 2003). Imbauan takut, imbauan yang mencemaskan mengancam, meresahkan dan dapat mempengaruhi jiwa orang lain. Imbauan ganjaran menggunakan rujukan yang menjadikan komunikate sesuatu yang mereka perlukan. Imbauan motivasional menggunakan imbauan motif (motive appeals) yang menyentuh kondisi intern diri manusia. setiap imbauan baik itu yang bersifat rasional, 
emosional, takut, ganjaran dan motivasional selain bersifat menghimbau atau mengajak namun juga memiliki nilai-nilai dakwah yang kegunaanya untuk memberi pemahaman kepada pembaca mengenai ajaran Islam melalui cerita, pengemasan ajaran islam tersebut tidak bersifat teoritis seperti yang terdapat pada buku-buku yang membahas seputar keagamaan namun pesan disampaikan secara rekreatif serta edukatif sehingga hal tersebut membuat pembaca dalam hal ini sebagai objek dakwah secara tidak langsung dapat memahami ajaran Islam dari serangkaian alur cerita, kalimat dan ungkapan-ungkapan yang terdapat pada novel. Pada setiap imbauan, secara tidak langsung dapat mempengaruhi proses penyampaian pesan dakwah dari Da'i terhadap Mad'u secara umum pada hakikatnya pemahaman mengenai dakwah adalah seruan dan ajakan untuk manusia kepada jalan Allah. Dan berbagai imbauan makna dakwah dalam novel Bait Surau, memuat imbauan makna yang sangat mendalam, sehingga hal tersebut dapat mempengaruhi pikiran pembaca sebagai objek dari dakwah.

Motivasi adalah suatu kekuatan penggerak dalam perilaku individu baik yang akan menentukan arah maupun daya tahan (perintence) tiap perilaku manusia yang di dalamnya terkandung pula unsur-unsur emosional insani yang bersangkutan. Motivasi juga dapat diartikan sebagai dorongan (driving force) dimaksudkan sebagai desakan yang alami untuk memuaskan dan mempertahankan kehidupan. Motivasi berfungsi sebagai daya penggerak dari dalam individu untuk melakukan aktivitas tertentu dalam mencapai tujuan (Fatoni, 2003: 12).

Dari analisis yang telah penulis lakukan, ditemukan pesan-pesan dakwah dalam novel Bait Surau lebih banyak mengutarakan imbauan motivasional, yang mana imbauan motivasional mengajak dan menghimbau pembaca agar melakukan sesuatu hal yang baik dan bermanfaat. Kecenderungan imbauan pesan dakwah terbanyak dalam novel Bait Surau terdapat pada imbauan motivasional, dari jumlah keseluruhan terhitung 42 ungkapan. Novel Bait Surau mengandung imbauan pesan yang mengindikasikan pesan dakwah.

\section{Kategori Pesan Dakwah dalam Novel Bait Surau}

Berdasarkan hasil analisis terhadap penjelasan serta ungkapan-ungkapan di dalam novel Bait Surau mengenai Kategori Pesan Dakwah, maka kesemuanya itu dapat dimasukan ke dalam sebuah tabel sebagai berikut: 
Muhamad Ripai, Ucin Muksin, \& Dadan Anugrah

Tabel 2 Presentase Kategori Substansi/Isi

\begin{tabular}{cccc}
\hline Kategori Isi & Halaman & Keterangan & Jumlah \\
\hline Akhlak & $45,53,67,68,78,81,82$, & - & 8 \\
Ibadah & $44,49,51,58,59,70,83$, & - & 10 \\
Syariah & $103,115,127$ & $51(3 \mathrm{X}), 102$ & 9 \\
& $51,55,101,102,127$ & $(3 \mathrm{X})$ & 27 \\
\hline
\end{tabular}

Dari keterangan tabel 2 diketahui bahwa pesan-pesan dakwah yang terdapat pada novel Bait Suran banyak membahas yang termasuk ke dalam kategori ibadah, sedangkan yang paling sedikit pembahasannya terdapat pada kategori akhlak.

Hasil penelitian pada novel Bait Surau di atas dapat ditarik kesimpulan bahwa pesan yang lebih banyak di bahas dalam novel ini adalah mengenai permasalahan Ibadah.

Ibadah merupakan penyembahan yaitu ajaran atau tatacara menyembah Allah swt. Ajaran mengenai ibadah disusun dalam suatu ilmu yang disebut syariah atau fiqih. Secara prinsip ilmu syariah atau fiqih membahas tentang rukun islam, yaitu: syadat, shalat, zakat, puasa dan haji. (kisi-kisi ujian komprehenshif, 2014:40).

Ibadah merupakan suatu ketaatan seorang hamba kepada Allah swt, dan bentuk ketaatan itu direalisasikan dengan amal perbuatan tersebut bermacam-macam yang antara lain seperti shalat, zakat, puasa, dll.

Dengan demikian pengertian ibadah merupakan bentuk ketundukkan, kepatuhan, ketaatan manusia kepada Allah swt, dan dinyatakan dengan kegiatan-kegiatan dan tindakan yang diniatkan sematamata karena mengharap ridha Allah dan berpedoman pada Al-Qur'an dan Hadits, dalam islam contohnya shalat, zakat, puasa, dll.

Setelah ibadah novel ini pun banyak bercerita dan membahas seputar akhlak, menurut buku (kisi-kisi ujian komprehenshif, 2014:8), akhlak yang merupakan perilaku baik dan buruk manusia yang nilai atau ukurannya mengacu pada Al-Qur'an dan Sunah dan berlaku universal. Pengertian lain adalah perilaku baik dan buruk manusia yang nilai atau ukurannya mengacu pada ajaran agama yang bersumber pada Al-Qur'an dan Sunah dan berlaku secara universal.

Akhlak yang berkenaan dengan sikap baik atau buruk, juga tingkah 
laku, akhlak merupakan perangai karakteristik manusia, akhlak menggambarkan pribadi manusia, akhlak merupakan bentuk yang memiliki nilai tersebut dapat terbentuk antara lain dari kebiasaan diri maupun lingkungan sekitar.

Perkataan "akhlak" berasal dari bahasa Arab 'jama' dari "khulqun" yang menurut bahasa, diartikan: budi pekerti, perangai, tingkah laku atau tabiat (Yakub, 1983: 11).

Pengertian akhlak sifat atau tingkah laku. Islam menerangkan kelakuan yang baik dan jelek. Seorang muslim harus berakhlak baik, yaitu: jujur, adil, amanah, percaya diri (istiqomah), sopan, tawadlu atau rendah hati dan lain-lain. Selain itu juga diharuskan meninggalkan hal-hal yang jelek, seperti: berbohong, tidak adil, khianat, sombong, curang, dan lain-lain. (kisikisi ujian komprehenshif, 2014:40).

Dengan demikian akhlak dapat diartikan sebagai budi pekerti, sikap, kelakuan, kepribadian, tindakan dan sebagainya. Banyak faktor yang membentuk karakter akhlak seseorang antara lain seperti lingkungan, pergaulan dan masyarakat, namun sesungguhnya pembentukkan akhlak terbentuk dari diri sendiri.

Betapapun berada pada lingkungan yang kurang begitu baik, namun bila seseorang itu memiliki sikap jiwa yang telah terarah secara sadar dalam dirinya maka dapat dipastikan tidak akan terbawa terhadap arus negatif, maka dia sudah dapat mengendalikan diri dengan cara menjaga sikap serta menjaga akhlaknya, oleh karenanya lingkungan khususnya menjadi aspek yang mendasar dan teramat penting dalam upaya menumbuhkembangkan akhlak seseorang, lingkungan memerankan peran paling utama untuk membentuk akhlak seseorang.

Dapat diambil kesimpulan mengenai akhlak, akhlak yang sering diartikan sikap, tingkah laku dan kepribadian merupakan salah satu hal yang teramat penting bagi setiap manusia, yang dalam hal ini khususnya adalah seorang muslim, sosok muslim sesungguhnya haruslah memiliki akhlak yang mulia, karena akhlak menjadi ciri khas bagi seorang muslim, bila setiap pribadi muslim memiliki akhlak mulia, tentunya akan mempengaruhi kemajuan suatu masyarakat, akhlak mulia akan memberi dampak positif baik bagi peradaban, masyarakat, bangsa, agama, dan negara secara luas.

Selain membahas pesan-pesan seputar ibadah dan akhlak, novel ini pun memuat seputar permasalahan yang berkaitan dengan syariah sebagai bentuk pesan dakwah yang diungkapkan melalui cerita, untuk permasalahan yang berkaitan dengan syariah ini menempati posisi kedua. 
Syariat, isi hukum agama yang menetapkan peraturan hidup manusia, hubungan manusia dengan Allah swt, hubungan manusia dengan manusia dan alam sekitar berdasarkan Al-Qur'an dan Hadits. (Kamus Besar Bahasa Indonesia, 2007:1115).

Syariat atau syariah yang merupakan seperangkat aturan lengkap yang memuat sejumlah norma secara terperinci yang berfungsi sebagai aturan, syariat menjadi tolak ukur untuk mengatur suatu hal agar terjadi keserasian.

Seruan dakwah Islam esensinya adalah keseluruhan ajaran Islam itu sendiri yang bertumpu pada Al-Qur'an dan Hadits, perintah untuk amal ma'ruf nahi munkar, perintah untuk bertakwa, menjalankan segala perintahnya dan menjauhi segala larangannya. Rasul adalah cerminan akhlak mulia contoh suri tauladan yang baik bagi umat manusia.

Ketika Allah menciptakan manusia yang mana tugasnya menjadi khalifah di muka bumi ini, Allah pun menciptakan peraturan untuk menjadi petunjuk untuk menuntun hidup manusia, peraturan tersebut ialah AlQur'an dan seluruhnya aturan hukum-hukum Islam dalam Al-Qur'an tersebut menjadi pedoman utama kehidupan manusia dan aturan tersebut bernama syariah.

Di dalam kisi-kisi ujian komprehensif, syariah membahas seputar Islam, sedangkan agama Islam sendiri menurut bahasa adalah, Islam berasal dari kata "salama" yang bersinonim dengan kata "solama" (damai), salamatan (selamat), Islam masdar dari: aslama, yuslamu, aslaman, menurut istilah Islam adalah agama ciptaan Allah yang mengajak orang berakal untuk menerima dan mengamalkan ajaran-Nya untuk kebahagiaan manusia di dunia dan di akhirat.

Syariah dalam Islam sangat erat kaitannya dengan apa yang disebut dengan habluminallah dan habluminanas, yakni keseluruhan perturan dan hukum Allah untuk mengatur hubungan antara manusia dengan Allah dan mengatur hubungan tata pergaulan hidup antara sesama manusia.

Aturan syariah Islam menjadi tuntunan lengkap dan menyentuh segala aspek ranah kehidupan manusia sebagi pedoman hidup dan menjadi jalan untuk terus meningkatkan kualitas keimanan dan ketakwaan.

Dalam novel Bait Surau terdapat banyak mengungkapkan berbagai maksud-maksud tersembunyi dibalik cerita, pesan-pesan yang tertangkap jelas melalui makna-makna yang tersirat, seperti contohnya ada yang menyangkut kedalam kategori akhlak, ibadah dan syariah.

Dan khusus untuk syariah, yang sering diartikan aturan hukum atau aturan Islam ini merupakan bagian penting yang sangat berpengaruh pada 
keseluruhan ajaran Islam, karena syariah tentunya yang menjadi dasar utama ajaran Islam.

Dari analisis yang telah penulis lakukan, ditemukan pesan-pesan dakwah dalam novel Bait Surau lebih banyak membahas seputar masalah ibadah dan syariah, yang mana kedua hal tersebut menjadi hal yang utama dan penting artinya, isi novel Bait Surau ini bukan sekedar untuk dibaca, namun nilai-nilai keislamannya dapat direalisasikan, dengan begitu wawasan serta pemahaman pembaca terhadap Islam akan semakin bertambah, disertai pengaplikasian tindakan dalam kehidupan nyata, serta dalam penyajian pun novel ini menggunakan bahasa yang sederhana, mudah dipahami, tidak berbelit-belit, ringkas, singkat namun padat makna, sehingga mudah dimengerti dan dicerna oleh pembaca.

Tabel 3 Kategori Bentuk Pesan

\begin{tabular}{cccc}
\hline Kategori Bentuk & Halaman & Keterangan & Jumlah \\
\hline Informatif & $41,48,58,59,67,68,83,91$, & $95(2 \mathrm{X})$ & 13 \\
Persuasif & $95,102,126,132$ & $106(2 \mathrm{X})$ & 4 \\
Instruktif & $12,64,106$ & - & 8 \\
& $7,13,50,54,78,79,101,114$ & Jumlah & 25 \\
\hline
\end{tabular}

Tabel 3 menunjukan bahwa dalam keseluruhan pesan dakwah novel Bait Surau yang termasuk ke dalam bentuk informatif terdapat sebanyak 10 kali ungkapan yaitu terdapat pada halaman 41, 48, 58, 59, 67, 68, 83, 91, 95 (2X), 102, 126, 132.

Informatif menurut kamus besar bahasa Indonesia berarti menerangkan, dalam hal ini berkaitan dengan pesan dakwah, yakni pesan dakwah yang informatif yang mencoba menerangkan mengenai suatu maksud, pesan dakwah informatif bertujuan untuk menginfomasikan, memperkenalkan, memberitahu sebuah pemahaman yang belum diketahui.

Sebuah informasi menjadi sebuah hal yang sangat penting artinya untuk disampaikan agar diketahui oleh orang lain, seperti contohnya disini adalah informasi yang berkaitan dengan ajaran Islam seperti misalnya tata cara pelaksaan beribadah yang benar sesuai dengan kaidah dan aturan yang sudah seharusnya diketahui agar terpahami oleh kaum muslim.

Setiap alur cerita dalam novel ini banyak mengandung pesan yang bersifat informatif, pesan tersebut bertujuan untuk memberikan informasi dalam hal ini pembaca agar paham dan mengerti akan nilai-nilai yang 
terdapat pada setiap halamannya, sebuah pesan dakwah yang baik haruslah dapat tersruktur dan juga informatif, tujuannya agar pesan-pesan keagamaan dapat terpahami oleh komunikan dalam hal ini pembaca.

Kedua, pesan dakwah yang termasuk ke dalam bentuk persuasif sebanyak 2 kali ungkapan terdapat pada halaman 12, 64, 106 (2X). Persuasif yakni mengajak secara halus, persuasif merupakan kegiatan yang memiliki tujuan untuk mempengaruhi pemikiran, tindakan, tingkah laku, sikap seseorang atau orang banyak.

Kaitannya dengan hal ini yakni dakwah secara persuasif berarti dakwah yang diungkapnkan dengan metode mengajak dengan cara mempengaruhi komunikan, metode ini lebih terkonsentrasi pada bagaimana agar komunikan memahami apa yang disampaikan oleh komunikator.

Dalam novel ini bentuk persuasi merupakan salah satu bentuk ajakan atau seruan kepada komunikan dalam hal ini mad'u khususnya sebagai pembaca, dan pesan yang berupa ajakan yang dibuat oleh komunikator dalam hal ini ialah penulis novel tersirat dengan jelas di setiap kisahnya, dan pembaca akan dapat menangkap ungkapan-ungkapan persuasif yang merupakan bagian dari pesan dakwah dalam novel.

Metode persuasif ini sangat sesuai diterapkan dalam aktivitas dakwah dengan beragam media, karena melalui pola struktur persuasif yakni mempengaruhi mad'u akan lebih cepat tanggap dan paham akan materi dakwah yang disampaikan.

Sedangkan yang termasuk kategori Instruktif terdapat 8 kali, yang terdapat pada halaman $7,13,50,54,78,79,101,114$. Istruktif yang bisa berarti perintah, sebuah perintah biasanya menjadi sebuah keharusan dan adalakalanya menjadi tugas dan kewajiban, secara objektif kategori instruktif pada sebuah novel dakwah religius seperti novel Bait Surau secara tidak langsung mampu memanipulasi pikiran pembaca, yang pada akhirnya membuat pembaca tertarik untuk memahami ajaran Islam.

Allah swt pun di dalam Al-Qur'an banyak memberikan contoh gambaran instruktif kepada hambanya, bentuk instruktif tersebut datang dari Allah swt melalui perantara utusannya dan termaktub dalam Al-Qur'an berupa ayat-ayat, salah satu bentuk instruktif yang terdapat pada Al-Qur'an yakni pada pelaksanaan ibadah yang sesungguhnya haruslah dilaksanakan dan dijalankan sesuai dengan ketentuan syara sesuai kaidah keislaman atau hukum-hukum yang berlaku.

Setelah melalui berbagai tahapan penelitian, diketahui bahwa 
keseluruhan pesan dakwah yang termasuk kedalam kategori bentuk informatif sebanyak 13 kali ungkapan, pesan dakwah yang termasuk ke dalam kategori bentuk persuasif sebanyak 4 kali ungkapan, dan yang termasuk ke dalam kategori bentuk instruktif terdapat 8 kali ungkapan.

Dari seluruh langkah-langkah yang telah dilakukan dan melalui tahapan kalkulasi kategori pesan dakwah akhirnya ditemukan bahwa jumlah terbanyak terdapat pada kategori informatif, pada hakikatnya sebuah pesan dapat disampaikan melalui beragam metode dan cara, seperti halnya dalam novel Bait Surau, pesan dakwah lebih banyak disampaikan secara informatif, hal ini mengindikasikan bahwa pesan dakwah dalam novel ini bersifat informatif atau memberitahukan. Melalui ungkapan-ungkapan cerita yang memuat pesan-pesan dakwah yang relevan sarat makna, membuat pembaca menjadi luas pemahaman seputar keislaman, karena pada dasarnya AlQur'an pun sebagai kitab suci memuat lengkap banyak informasi.

Berdasarkan hasil analisis, dari kedua tabel tersebut di atas begitu jelas menunjukan bahwa pada setiap lembar bab memiliki koherensi yang saling berkaitan, setelah dikaji dan melalui proses analisis yang meliputi: pengklasifikasian, pengumpulan dan observasi terhadap novel Bait Surau diketahui bahwa banyak ditemukan bentuk pesan dakwah yang beragam baik dari segi substansi maupun bentuk serta imbauan-imbauan pesan yang berbeda dengan beragam fungsi dan tujuannya, kesemua hal tersebut mengindikasikan pada setiap kisah-kisah pada novel tersebut terdapat beragam imbauan, kategori substansi serta bentuk pesan yang berbeda.

Novel pada saat ini menjadi media dakwah yang baik sekaligus praktis, untuk menjadi media dakwah yang baik tentulah harus dapat memuat hal-hal yang berkenaan dengan nilai-nilai dakwah secara tepat guna agar mengena khususnya kepada pembaca yang berarti bahwa selain novel tersebut bersifat menghibur namun juga memuat unsur-unsur keislaman.

Dari judulnya, novel ini mengisahkan secara jelas mengenai bagaimana alur cerita yang terdapat di dalamnya yakni menceritakan tentang kehidupan Rommy yang digambarkan sebagai pria yang tidak pernah puas dengan kehidupannya. Hidup Rommy lebih banyak di habiskan dengan menyianyiakan segala yang dia miliki. Mulai dari mabuk-mabukan, keluar malam hingga sifatnya yang suka sekali berganti-ganti wanita. Padahal Romy telah memiliki seorang isteri yaitu Nadia. Apalagi Nadia terkenal dengan sifatnya yang terpuji dan akhlaknya yang mulia. Namun sepertinya hal tersebut belum pernah membuat Rommy berhenti dengan segala sifatnya yang buruk. Karena Rommy seakan tidak pernah mensykuri segala 
Muhamad Ripai, Ucin Muksin, \& Dadan Anugrah

sesuatu yang telah ia miliki.

Suatu kali karena tidak tahan dengan sifat suaminya, Nadia memutuskan untuk menegur Rommy dan berharap dia bisa memperbaiki segala sifatnya yang buruk tersebut. Namun alih-alih mendengarkan nasihat dari isterinya, Rommy merasa Nadia terlalu ikut campur dengan hidup yang ia pilih. Mereka berdua pun terlibat dalam pertengkaran yang hebat. Tidak satupun dari mereka yang memutuskan untuk menghentikan pertengkaran tersebut.

Secara keseluruhan, novel ini mengulas secara mendetail mengenai bagaimana seseorang yang tidak puas akan kehidupannya yang serba berkecukupan ia malah menyalahgunakan kesempatan yang telah diberikan. Yang seharusnya ia bersyukur atas apa yang telah diberikan Allah kepadanya, ia sebaiknya mengambil sikap yang bijaksana dalam setiap kehidupannya, mengambil langkah yang baik untuk kehidupannya di masa yang akan datang dan menerima segala sesuatu dengan bersyukur dan menanggapinya dengan positif. Selain itu novel ini banyak menceritakan tentang kehidupan para tokoh-tokohnya yang memiliki nilai-nilai keagamaan dan nilai-nilai keagamaan itu sekaligus menjadi pesan dakwah untuk para pembacanya.

Melalui novel karya Rakha Wahyu dan Yus R Ismail tak hanya menyuguhkan alur cerita yang rekreatif, tak sekedar itu namun mengandung pesan-pesan dakwah yang bersifat informatif, persuasif dan instruktif termuat pula imbauan-imbauan rasional, emosional, takut, ganjaran dan motivasional serta banyak ditemukan pesan-pesan dakwah sarat makna dan juga hikmah dan setiap imbauan dan pesan dakwah yang terdapat pada novel ini memiliki fungsi yang berbeda, setelah membaca novel hingga selesai akan terasa kepada pembaca beragam pesan kebaikan nan inspiratif serta menggugah terdapat pada novel ini.

Berdasarkan hasil analisis yang telah dilakukan, dapat dimasukan ke dalam tabel dan gambar seperti dibawah ini:

Tabel 4 Posisi nomor urut imbauan pesan

\begin{tabular}{cc}
\hline Nomor Posisi & Imbauan Pesan \\
\hline 1 & Motivasional \\
2 & Emosional \\
3 & Takut \\
4 & Rasional \\
5 & Ganjaran \\
\hline
\end{tabular}


Dari tabel 4 diketahui antara lain sebagai berikut 1) Imbauan Motivasional menempati jumlah yang paling banyak, 2) Imbauan Emosional menempati jumlah kedua paling banyak, 3) Imbauan Takut menempati jumlah ketiga paling banyak, 4) Imbauan Rasional menempati jumlah keempat rendah, dan 5) Imbauan Ganjaran menempati jumlah paling rendah.

Tabel 5 Posisi nomor urut kategori isi pesan

\begin{tabular}{cccc}
\hline $\begin{array}{c}\text { Nomor } \\
\text { Posisi }\end{array}$ & $\begin{array}{c}\text { Kategori } \\
\text { Substansi }\end{array}$ & $\begin{array}{c}\text { Nomor } \\
\text { Posisi }\end{array}$ & $\begin{array}{c}\text { Kategori } \\
\text { Bentuk }\end{array}$ \\
\hline 1 & Ibadah & 1 & Informatif \\
2 & Syariah & 2 & Instruktif \\
3 & Akhlak & 3 & Persuasif \\
\hline
\end{tabular}

Dari tabel 5 diketahui, antara lain sebagai berikut: 1) Kategori Ibadah menempati jumlah yang paling banyak, 2) Kategori Syariah menempati jumlah kedua paling banyak, 3) Kategori Akblak berada pada jumlah paling rendah, 4) Kategori Informatif menempati posisi yang paling banyak, 5) Kategori Instruktif menempati posisi kedua paling banyak, dan 6) Kategori Persuasif berada pada posisi paling rendah

Berdasarkan hasil analisis dan keterangan gambar yang menerangkan kesimpulan analisis keseluruhan novel, terlihat jelas bahwa imbauan motivasional lebih mendominasi ketimbang imbauan yang lain. Dan kategori ibadah dan instruktif lebih mendominasi ketimbang yang lain, karena begitu seringnya ditemukan dalam novel Bait Surau.

Secara integral novel Bait Surau umumnya memiliki banyak pesanpesan dakwah, yang memberikan gambaran bagaimana seorang manusia dalam menjalani kehidupannya yang diniatkan ibadah dengan hati yang ikhlas dalam rangka menggapai ridho Ilahi sebagai manifestasi keimanan, dan secara tidak langsung pengarang ingin memberikan pemahaman tentang agama Islam kepada pembaca mengenai hal-hal apa saja yang dibolehkan serta yang dilarang, mengenai bagaimana akhlakul karimah, tata cara beribadah, mengenai syariah dan lain hal sebagainya yang tentunya dari kesemua hal tersebut memuat banyak hikmah dan manfaat yang dapat dipetik.

Dengan demikian dari hasil di atas dapat disimpulkan bahwa beragam kisah yang tersaji dalam novel Bait Surau, merupakan serangkaian alur cerita yang menginspirasi, memiliki nilai-nilai keagamaan yang menyimpan 
Muhamad Ripai, Ucin Muksin, \& Dadan Anugrah

banyak makna kehidupan, pesan yang disampaikan penulis dalam novel Bait Surau lebih bersifat motivasional dan informatif dengan gaya bahasa sederhana mudah dipahami oleh pembaca dengan cara penyajian yang lebih banyak bersifat motivasional dan informatif dan inilah yang membuat novel ini menjadi novel yang memunculkan hal-hal yang belum diketahui pembaca, hal-hal tersebut tentunya menjadi pengetahuan dan menambah wawasan keislaman bagi pembaca.

Selain itu pesan-pesan dakwah seperti akhlak, ibadah dan syariah yang terdapat pada novel secara tidak langsung memberikan gambaran mengenai sikap, kepribadian, nilai-nilai kehidupan, nilai-nilai kemanusiaan, nilai-nilai sosial, budaya masyarakat dan lain sebagainya yang kesemuanya itu memiliki nilai-nilai positif yang sangat baik bagi pembaca.

\section{PENUTUP}

Berdasarkan proses hasil penelitian terhadap data yang dikumpulkan maka dapat diambil beberapa kesimpulan, sebagai berikut: Pertama, Novel Bait Surau merupakan karya prosa yang dapat dijadikan sebagai media dakwah . Hal ini dikarenakan dalam Novel Bait Surau mengandung pesan dakwah baik dalam imbauan maupun kategori pesan. Pesan dakwah yang terdapat dalam Novel Bait Surau beraneka ragam, terwujud pada ungkapanungkapan yang mengindikasikan pesan dakwah didalamnya.

Kedua, Imbauan pesan dakwah dalam novel Bait Surau, terwujud pada ungkapan-ungkapan sebagai imbauan yang mengindikasikan pesan dakwah. Setelah melalui proses pengklasifikasian ditemukan bahwa imbauan pesan motivasional sebagai aspek imbauan pesan dakwah yang lebih mendominasi daripada imbauan yang lainya yaitu imbauan rasional, imbauan emosional, imbauan takut dan imbauan ganjaran paling sedikit disebutkan dalam novel Bait Surau. Sehingga diperoleh imbauan pesan dakwah yang terwujud pada beberapa ungkapan yang mengindikasikan imbauan motivasional.

Kategori substansi berkaitan dengan isi pesan sesuai dengan sifat spesifik dari isi cerita dan tema novel. Dalam novel ini memuat banyak pemasalahan-permasalahan yang kompleks antara lain menyangkut: permasalahan akhlak, ibadah dan syariah. Dan untuk kategori ibadah dalam novel ini berada pada posisi materi dakwah paling banyak dan kategori akhlak paling sedikit, hal ini berarti mengenai pemahaman ibadah dikumpas secara mendetail baik itu kalimat maupun percakapan-percakapan yang tergambar dari berbagai ungkapan baik itu dari kata, kalimat maupun 
dialog-dialognya, dengan demikian dapat diambil kesimpulan bahwa kategori ibadah menjadi kategori pesan dakwah yang paling banyak dibahas dalam novel ini ketimbang kategori yang lain.

Kategori bentuk merupakan kategori yang khusus mengkaji mengenai tekhnik komunikasi untuk disampaikan kepada komunikan. Tekhnik tersebut antara lain terbagi menjadi tiga, yakni tekhnik informatif, persuasif dan instruktif. Setelah melalui proses pengklasifikasian ditemukan tekhnik informatif dalam novel ini berada pada posisi materi dakwah paling banyak dan tekhnik persuasif paling sedikit, hal ini mengindikasikan unsur informatif lebih mendominasi dalam novel ini, yang mana unsur informatif tersebut lebih bersifat memberitahu tentang berbagai hal kepada pembaca, dari informasi tersebut dimaksudkan agar pembaca paham dan mengetahui segala informasi yang berkaitan dengan ajaran Islam.

\section{DAFTAR PUSTAKA}

Aripudin, A. dan Ridwan, M. R. (2009) Materi Dakwah pada Grup Ban Non-Religi (Analisis Pesan Dakwah dalam Lirik Lagu Grub Band GIGI) dalam Ilmu Dakwah: Academic Journal for Homiletic Studies 4(13) 493-512

Bachtiar, W. (1997). Metodelogi Penelitian Ilmu Dakwah, Jakarta: Logos Kencana Prenada.

Burhan, N. (2002). Teori Pengembangan Fiksi. Yogyakarta: Gajah Mada Perss. Departemen Pendidikan Nasional. Kamus Besar Babasa Indonesia (KBBI), (2008). Pusat Bahasa Edisi IV, Jakarta: PT Gramedia Pustaka Utama. Effendy, O. U. (1990). Ilmu Komunikasi Teori dan Praktek. Bandung: PT. Remaja Rosdakarya.

Enjang A.S. \& Aliyudin. (2009). Dasar-Dasar Ilmu Dakwah. Bandung: Widya Padjadjaran.

Enjang AS, \& Tajiri, H. (2009). Etika Dakwah. Bandung: Widya Padjajaran. Fatoni, U. (2003). Kredibiltas Kunci Sukses Muballigh. Bandung: Task Press. Kamil, S. 2012. Teori Kritik Sastra Arab. Jakarta: Raja Grafindo Persada.

Kusnawan, A. (2004). Berdakwah Lewat Tulisan. Bandung: Benang Merah Pers

Muhyiddin, A. (2002). Dakwah dalam Perspektif Al-Quran. Bandung: Pustaka Setia.

Mulyana, D. (2007). Imu Komunikasi. Bandung: Rosdakarya. 
Muhamad Ripai, Ucin Muksin, \& Dadan Anugrah

Niamul, H. Dkk. (1993). Kamus Pelajar Populer. Pekalongan: CV. Bahagia Bintang.

Panuti, S. (1990). Kamus Istilah Sastra. Jakarta Universitas Indonesia.

Rakhmat, J. (2005). Metode Penelitian Komunikasi. Bandung: PT Remaja Rosdakarya.

Rakhmat, J. (2011). Psikologi Komunikasi. Bandung: PT Remaja Rosdakarya.

Sayuti S. A, (1996). Apresiasi Prosa Fiksi. Jakarta: Depdikbud, Dirjen Dikdasmen, BPPG SLTP Setara D-III.

Subandi, A. (1994). Ilmu Dakwah, Pengantar Kearah Metodologi. Bandung: Syahida.

Sugiyono. (2012). Metode Penelitian Kuantitatif Kualitatif dan R\&D. Bandung: Alfabeta.

Sumardi, Jacob Dkk. (1986). Apresiasi Kesusastraan. Jakarta: Gramedia.

Syukir, A. (1983). Dasar-Dasar Strategi Islam. Surabaya: Al-Ikhlas.

Tim Penyusun (2013). Panduan Penyusunan Skripsi Bandung: Fakultas Dakwah dan Komunikasi UIN Sunan Gunung Djati. 